Jurnal Ilmu Ilmu Agribisnis: Journal of Agribusiness Science, 9(3), Agustus 2021

\title{
KETAHANAN PANGAN RUMAH TANGGA PETANI KELAPA SAWIT DI KECAMATAN BANGUNREJO KABUPATEN LAMPUNG TENGAH
}

\author{
(Food Security of Palm Oil Farmer Households in Bangunrejo Subdistrict, \\ Central Lampung Regency)
}

\begin{abstract}
Alfu Mifta Khusufa, Dwi Haryono, Fembriarti Erry Prasmatiwi
Jurusan Agribisnis, Fakultas Pertanian, Universitas Lampung, Jl. Prof. Dr. Soemantri Brojonegoro No. 1 Bandar Lampung 35141,e-mail: dwi.haryono@fp.unila.ac.id
\end{abstract}

\begin{abstract}
The aims of this research are to analyze the level of food security, the factors that influence the level of household food security, and efforts to increase the level of food security of palm oil farmer households. The location of this research is chosen purposively in Bangunrejo Sub district, Central Lampung Regency in which respondents are 75 palm oil farmers household. The data were collected in January - March 2019 using a survey method and analyzed using cross-classification between the share of food expenditure and energy adequacy level, ordinal logistic regression, and descriptive qualitative analysis. The results of the research showed that the majority of farmer households (61.33\%) were classified as food secure, and the rest were classified as less food secure (28\%), vulnerable to food (9.33\%), and food insecure (1.33\%). The affecting factors on the level of food security were formal education level of housewives, households' income, and number of household members. The efforts to increase the level of food security by Government were through monitoring food availability and food reserves, developing food distribution and stabilization of food prices, Program Keluarga Harapan (PKH), Raskin, and Bantuan Pangan Non Tunai (BPNT). Whereas, the efforts by palm oil farmer households were food loan (93.33\%) and changing dietary habit $(6.67 \%)$.
\end{abstract}

Key words: cross-clasification, food security, palm oil farmer households

\section{PENDAHULUAN}

Subsektor perkebunan merupakan salah satu subsektor penting dalam sektor pertanian Indonesia. Salah satu komoditas unggulan perkebunan yang memiliki kontribusi dalam perekonomian di Indonesia adalah kelapa sawit. Kelapa sawit menyumbang sebesar 60,60 persen dari total Produk Domestik Bruto (PDB) pada sub sektor perkebunan (BPS 2018a). Tingginya kontribusi tanaman perkebunan terhadap perekonomian disebabkan produksi perkebunan lebih tinggi dibanding dengan tanaman lainnya. Rata-rata perkembangan luas areal perkebunan dan produksi kelapa sawit di Indonesia pada tahun 2013 - 2017 meningkat sebesar 2,90 persen dan produksinya meningkat sebesar 19,43 persen.

Kelapa sawit di Kabupaten Lampung Tengah memiliki prospek yang baik dilihat dari luas areal dan jumlah produksi kelapa sawit yang tinggi. Kecamatan Bangunrejo merupakan sentra produksi kelapa sawit di Kabupaten Lampung Tengah, yaitu menyumbang sebesar 25,38 persen dari total produksi kelapa sawit di Kabupaten Lampung Tengah. Perkebunan kelapa sawit di Kecamatan
Bangunrejo umumnya diusahakan oleh perkebunan rakyat.

Berdasarkan hasil penelitian rata-rata petani kelapa sawit menggantungkan hidupnya dari hasil produksi usahatani padi. Hal tersebut dikarenakan pendapatan usahatani padi per tahun lebih besar dibandingkan dengan pendapatan usahatani kelapa sawit per tahun dan luas lahan kelapa sawit yang dimiliki tergolong kecil, sehingga hasil produksinya belum mampu untuk mencukupi kebutuhan rumah tangga. Tinggi atau rendahnya pendapatan rumah tangga petani akan menentukan jenis dan jumlah pangan yang dikonsumsi dan secara tidak langsung akan berpengaruh pada tingkat ketahanan rumah tangga petani.

Kabupaten Lampung Tengah termasuk daerah yang tahan pangan, namun ketahanan pangan di tingkat kabupaten belum dapat menjamin ketahanan pangan di tingkat rumah tangga petani kelapa sawit. Berdasarkan hasil penelitian Lalita, Ismono, dan Prasmatiwi (2018) petani kelapa sawit tergolong sejahtera, namun tingkat kesejahteraan petani tersebut belum tentu dapat menjamin tingkat ketahanan pangan. Hal ini dikarenakan 
rumahtangga petani kelapa sawit tersebut belum dapat mengalokasikan pendapatannya untuk memenuhi kebutuhan pangan di dalam rumah tangga.

Ketahanan pangan terdiri dari tiga aspek penting yaitu aspek ketersediaan, distribusi, dan konsumsi pangan. Ketersediaan pangan petani kelapa sawit dapat diperoleh melalui pembelian dan harus diperhatikan secara baik karena bersifat musiman dan terbatas, tetapi volume pangan yang tersedia harus cukup dalam jumlah dan jenisnya serta harus stabil penyediaannya dari waktu ke waktu. Distribusi pangan menyangkut pangan yang dikonsumsi dalam rumah tangga. Pangan yang ada diharapkan dapat tersebar secara merata di dalam suatu rumah tangga. Konsumsi pangan menyangkut pangan yang dikonsumsi dengan memperhatikan jenis pangan yang beragam, bergizi, dan berimbang sesuai dengan kebutuhan energi masing-masing rumah tangga untuk pembentukan manusia yang sehat, kuat, cerdas, dan produktif.

Agar mencapai kondisi tahan pangan, tiga aspek ketahanan pangan harus terpenuhi dengan baik. Penelitian tentang ketahanan pangan rumah tangga masih cukup sedikit, terutama di daerah sentra produksi kelapa sawit. Berdasarkan uraian di atas maka diperlukan penelitian yang ditujukan untuk menganalisis tingkat ketahanan pangan, faktorfaktor yang memengaruhi tingkat ketahanan pangan, dan upaya yang dilakukan rumah tangga petani untuk mencapai kondisi tahan pangan bagi rumah tangga petani kelapa sawit.

\section{METODE PENELITIAN}

Penelitian ini dilakukan secara purposive dengan menggunakan metode survei dengan pertimbangan bahwa Kecamatan Bangunrejo merupakan sentra produksi kelapa sawit di Kabupaten Lampung Tengah. Dengan pertimbangan yang sama kemudian diambil dua desa yaitu Desa Sidoluhur dan Desa Mekar Jaya. Metode pengambilan sampel menggunakan metode simple random sampling. Populasi penelitian adalah 1.700 petani kelapa sawit.

Tabel 1. Tingkat ketahanan pangan rumah tangga

\begin{tabular}{lcc}
\hline Konsumsi Energi & \multicolumn{2}{c}{ Pangsa Pengeluaran Pangan } \\
\cline { 2 - 3 } & Rendah $(<60 \%)$ & Tinggi $(\geq 60 \%)$ \\
\hline Cukup $(>80 \%)$ & Tahan & Rentan \\
Kurang $(\leq 80 \%)$ & Kurang & Rawan \\
\hline Sumber: Joonson dan Toole (1991) dalam Maxwell, et al $(2000)$
\end{tabular}

Penentuan sampel mengacu pada rumus Sugiarto (2003) yaitu:

$\mathrm{Ni}=\frac{\mathrm{NZ}^{2} \mathrm{~S}^{2}}{\mathrm{Nd}^{2}+\mathrm{Z}^{2} \mathrm{~S}^{2}}$

Keterangan:

$\mathrm{n} \quad=$ Jumlah sampel

$\mathrm{N} \quad=$ Jumlah populasi petani kelapa sawit

$\mathrm{S}^{2} \quad=$ Variasi sampel $(5 \%=0,05)$

$\mathrm{Z}=$ Derajat kepercayaan $(95 \%=1,96)$

$\mathrm{d}=$ Derajat penyimpangan $(5 \%=0,05)$

Berdasarkan perhitungan dengan rumus, maka diperoleh jumlah sampel sebanyak 75 petani, dengan masing-masing Desa Sidoluhur 62 petani dan Desa Mekarjaya 13 petani yang ditentukan berdasarkan rumus penentuan sampel secara proporsional, yaitu:

$\mathrm{Ni}=\frac{\mathrm{ni} \cdot \mathrm{n}}{\mathrm{N}}$

Keterangan:

ni $=$ Jumlah responden desa ke i

$\mathrm{Ni} \quad=$ Jumlah sub populasi desa ke $\mathrm{i}$

$\mathrm{n} \quad=$ Jumlah sampel

$\mathrm{N} \quad=$ Jumlah populasi

Jenis data yang digunakan adalah data primer dan data sekunder. Data primer diperoleh dari hasil wawancara secara langsung dari responden dengan menggunakan kuesioner berupa data konsumsi pangan menggunakan metode recall.. Data sekunder diambil dari instansi seperti BP3K, BPS, Kantor Desa serta data berupa literatur terkait.

Tujuan penelitian pertama dijawab dengan menggunakan indikator klasifikasi silang antara pangsa pengeluaran pangan dan kecukupan energi yang dikembangkan oleh Johnsson dan Toole

Data konsumsi riil pangan rumah tangga dihitung dengan rumus berikut.

$\mathrm{Gj}(\mathrm{A})=\left(\frac{B P \mathrm{Bj}}{100} \times \frac{\text { Bddj }}{100}\right) \times \mathrm{Kgj}$

Keterangan:

$\mathrm{Gj}(\mathrm{A})=$ Jumlah energi atau protein yang dikonsumsi dari pangan $\mathrm{j}$ (energi dalam satuan kkal dan protein dalam satuan gram)

$\mathrm{BPj}=$ Berat dari pangan $\mathrm{j}$ yang dikonsumsi (gram)

$\mathrm{KGj}=$ Kandungan energi atau protein per 100 
gram pangan $\mathrm{j}$ yang dikonsumsi energi dalam satuan kkal dan protein dalam satuan gram)

Bdd =Bagian yang dapat dimakan dari 100 gram pangan $\mathrm{j}(\%)$

Angka Kecukupan Energi (AKE) dihitung dengan rumus sebagai berikut:

$\mathrm{AKE}=\left(\frac{\mathrm{BB} \text { aktual }(\mathrm{kg})}{\mathrm{BB} \text { standar }(\mathrm{kg})}\right) \times \mathrm{AKE}$ standar

Keterangan:

AKE = Angka kecukupan energi

$\mathrm{BB}$ aktual $=$ Berat badan aktual

BB standar = Berat badan standar

AKE standar $=$ AKE anjuran WNPG 2012

Pangsa pengeluaran pangan dihitung dengan rumus sebagai berikut:

$\mathrm{PPP}=\frac{\mathrm{FE}}{\mathrm{TE}} \times 100 \%$

Keterangan:

PPP = Pangsa Pengeluaran Pangan (\%)

FE $\quad=$ Pengeluaran untuk Belanja Pangan (Rp/bulan)

TE $=$ Total Pengeluaran Rumah Tangga (Rp/bulan)

Tujuan penelitian ke dua dianalisis dengan regresi ordinal logit dengan persamaan berikut:

$$
\begin{array}{r}
P_{i}=F\left(Z_{i}\right)=F\left(\alpha+\beta X_{i}\right)=F\left(\alpha+\beta_{1} X_{1}\right)+\beta_{2} X_{2}+\beta_{3} X_{3}+ \\
\beta_{4} X_{4}+\beta_{5} X_{5}+\beta_{6} D_{1}+e \ldots \ldots \ldots \ldots \ldots \ldots \ldots \ldots \ldots \ldots \ldots \ldots \ldots \ldots \ldots \ldots \ldots \ldots \ldots \ldots \ldots \ldots
\end{array}
$$

Keterangan:

$\mathrm{P}_{\mathrm{i}} \quad=$ Peluang $\mathrm{P} 1=\mathrm{P}(\mathrm{Y}=4)$ untuk rumah tangga tani tahan pangan, Peluang $\mathrm{P} 2=\mathrm{P}(\mathrm{Y}=3)$ untuk rumah tangga tani kurang pangan, Peluang $\mathrm{P} 3=\mathrm{P}(\mathrm{Y}=2)$ untuk rumah tangga tani rentan pangan, Peluang $\mathrm{P} 4=\mathrm{P}(\mathrm{Y}=1)$ untuk rumah tangga tani rawan pangan

$\alpha \quad=$ Intersep

$\mathrm{X} 1$ = Jumlah anggota keluarga (Rp/tahun)

$\mathrm{X} 2$ =Pendidikan ibu rumah tangga (tahun)

$\mathrm{X} 3=$ Harga beras $(\mathrm{Rp} / \mathrm{kg})$

$\mathrm{X} 4$ =Harga telur $(\mathrm{Rp} / \mathrm{kg})$

$\mathrm{X} 5$ =Pendapatan (Rp)

$\mathrm{D}=$ =Akses terhadap pangan

Nilai 1 jika langsung (produksi padi)

Nilai 0 jika tidak langsung (tidak produksi padi)

e $=$ Error term
Estimasi model logit menggunkan uji Likelihood Ratio untuk mengetahui tingkat pengaruh seluruh variabel independen secara bersama-sama terhadap variabel dependen. Nilai Likelihood Ratio sama dengan Pseudo $R^{2}$. Pengujian masing-masing variabel independen terhadap variabel dependen dapat dilakukan dengan melakukan Uji Wald dengan distribusi normal.

Tujuan penelitian ke tiga dijawab dengan menggunakan analisis deskriptif. Upaya untuk mencapai kondisi tahan pangan dilakukan oleh pemerintah dan rumah tangga petani kelapa sawit untuk mencapai kondisi yang tahan pangan.

\section{HASIL DAN PEMBAHASAN}

\section{Karakteristik Petani}

Mayoritas usia kepala keluarga dan ibu rumah tangga petani kelapa sawit berkisar antara $36-51$ tahun $(40 \%)$. Pendidikan ibu rumah tangga dan pendidikan kepala keluarga didominasi oleh tingkat pendidikan SD yaitu masing-masing sebesar 37,33 persen dan 42,67 persen. Rata-rata jumlah anggota rumah tangga petani kelapa sawit berjumlah empat orang (44\%) yang berarti bahwa jumlah anggota rumah tangga memenuhi standar Norma Keluarga Kecil Bahagia dan Sejahtera (NKKBS) yaitu sebanyak $\leq 4$ orang per rumah tangga. Luas lahan kelapa sawit yang dimiliki berkisar 0,12 - 4 hektar, dengan rata-rata luas lahan 1,16 hektar. Sebagian besar petani kelapa sawit juga memiliki lahan sawah (72\%) dengan rata-rata luas lahan sebesar 0,28 hektar. Status kepemilikan lahan yang digunakan petani secara keseluruhan adalah milik sendiri. Pekerjaan pokok kepala keluarga adalah sebagai petani kelapa sawit. Selain pekerjaan pokok, kepala keluarga juga memiliki pekerjaan sampingan untuk menopang kehidupan rumah tangga.

Kepala rumah tangga yang memiliki pekerjaan sampingan sebesar 89,33 persen yaitu sebagai buruh pertanian, pedagang, bertani, beternak, sopir, pegawai swasta, pengrajin kayu, dan pegawai honorer, sedangkan 12 persen ibu rumah tangga memiliki pekerjaan sampingan sebagai pedagang, pegawai swasta, PNS, dan pegawai honorer. Ratarata total pendapatan rumah tangga petani kelapa sawit sebagian besar berasal dari pendapatan on farm bukan utama yaitu sebesar Rp11.784.066,67 per tahun yang dapat dilihat pada Tabel 2. 
Tabel 2. Rata-rata total pendapatan rumah tangga petani kelapa sawit

\begin{tabular}{lcr}
\hline Sumber pendapatan & Pendapatan $(\mathrm{Rp} / \mathrm{th})$ & \multicolumn{1}{c}{$\%$} \\
\hline Pendapatanon farm utama & $9.655 .952,00$ & 31,70 \\
Pendapatan on farm & & \\
bukan utama & $11.784 .066,67$ & 38,69 \\
Pendapatan off farm & $3.152 .000,00$ & 10,35 \\
Pendapatan non farm & $5.864 .000,00$ & 19,25 \\
\hline Total pendapatan & $30.456 .018,67$ & 100,00 \\
\hline
\end{tabular}

Mayoritas seluruh rumah tangga petani juga melakukan usahatani padi. Pendapatan on farm bukan utama lebih besar dari on farm utama dikarenakan sebagian besar rumah tangga petani kelapa sawit juga memiliki lahan sawah $(72 \%)$ untuk mencukupi kebutuhan rumah tangganya.

Rata-rata pendapatan rumah tangga petani kelapa sawit dalam satu bulan sebesar Rp2.538.001,56 atau Rp753.116,19/kapita/bulan yang mengindikasikan pendapatan per kapita rumah tangga petani kelapa sawit di Kecamatan Bangunrejo berada di atas standar garis kemiskinan masyarakat pedesaan yang ditetapkan oleh BPS Provinsi Lampung pada tahun 2014 - 2017 yaitu sebesar Rp377.049,00/kapita/bulan (BPS Provinsi Lampung 2018b).

\section{Ketahanan Pangan Rumah Tangga Petani Kelapa Sawit di Kecamatan Bangunrejo}

\section{Ketersediaan pangan}

Besarnya ketersediaan pangan pokok diukur dengan cara menginventarisasi pangan pokok (beras) yang tersedia dalam keluarga baik yang diperoleh dari input yaitu produksi usahatani, pembelian dan pemberian yang dikurangi dengan output rumah tangga yaitu dijual, aktivitas sosial, dan diberikan kepada pihak lain.
Merujuk Tabel 3 jumlah input ketersediaan pangan rumah tangga petani kelapa sawit di Kecamatan Bangunrejo adalah 2.917,10 kg gabah/tahun. Mayoritas input ketersediaan pangan berasal dari produksi usahatani padi yaitu 95,08 persen. Output pangan pokok di Kecamatan Bangunrejo adalah 2.224,15 kg gabah/tahun. Mayoritas output digunakan untuk dijual yaitu sebesar 96,73 persen, untuk aktivitas sosial sebesar 3,16 persen dan sisanya untuk aktivitas untuk diberikan kepada orang lain.

Ketersediaan pangan pokok rata-rata rumah tangga petani diperoleh dari nilai input dikurangi output adalah sebesar 1.152,26 kkal/kap/hari. Rata-rata besarnya ketersediaan pangan pokok (beras) adalah $36,97 \mathrm{~kg} / \mathrm{bulan} / \mathrm{RT}$. Rata-rata beras yang dikonsumsi rumah tangga petani kelapa sawit sebesar 255,85 gram/kapita/hari. Berdasarkan hasil kajian BPS (2015), konsumsi beras masyarakat Indonesia mencapai 312 gram per kapita per hari. Nilai tersebut menunjukkan bahwa rata-rata konsumsi beras rumah tangga petani padi tidak jauh berbeda dengan hasil kajian yang dilakukan oleh Badan Pusat Statistik.

Jika dilihat dari rata-rata ketersediaan pangan pokok beras dan rata-rata konsumsi beras oleh rumah tangga petani kelapa sawit di Kecamatan Bangunrejo, rata-rata ketersediaan pangan pokok adalah sebesar 320,07 gram/kapita/hari, sedangkan rata-rata konsumsi rumah tangga adalah sebesar 320,07 gram $/$ kapita/hari. Oleh karena itu, rumah tangga petani kelapa sawit di Kecamatan Bangunrejo mengalami surplus beras sebesar 64,22 gram/kapita/hari. Hal ini serupa dengan hasil penelitian Maryani, Prasmatiwi dan Adawiyah (2017) yang menyatakan rumah tangga petani padi anggota lumbung pangan di Kecamatan Ambarawa mengalami surplus beras sebesar 142,35 gram/kapita/hari.

Tabel 3. Ketersediaan pangan pokok rumah tangga petani kelapa sawit di Kecamatan Bangunrejo

\begin{tabular}{|c|c|c|c|c|c|c|}
\hline \multirow{2}{*}{ Keterangan } & \multirow{2}{*}{$\begin{array}{l}\text { Gabah } \\
\mathrm{Kg} / \mathrm{thn}\end{array}$} & \multicolumn{3}{|c|}{ Beras } & \multirow{2}{*}{$\begin{array}{c}\text { Energi } \\
\text { kkal/kap/hari }\end{array}$} & \multirow{2}{*}{$\%$} \\
\hline & & $\mathrm{Kg} / \mathrm{thn}$ & $\mathrm{Kg} / \mathrm{bLn}$ & g/kap/hari & & \\
\hline \multicolumn{7}{|l|}{ Input } \\
\hline Produksi & $2.773,60$ & $1.775,66$ & 147,97 & $1.281,14$ & $4.612,10$ & 95,08 \\
\hline Pembelian & 134,75 & 86,27 & 7,19 & 62,24 & 224,07 & 4,62 \\
\hline Raskin & 8,75 & 5,60 & 0,47 & 4,04 & 14,55 & 0,30 \\
\hline Jumlah (1) & $2.917,10$ & $1.867,53$ & 155,63 & $1.347,42$ & $4.850,72$ & 100,00 \\
\hline \multicolumn{7}{|l|}{ Output } \\
\hline Dijual & $2.151,33$ & $1.377,28$ & 114,77 & 993,71 & $3.577,36$ & 96,73 \\
\hline Aktivitas sosial & 70,19 & 44,93 & 3,74 & 32,42 & 116,71 & 3,16 \\
\hline Diberikan pihak lain & 2,63 & 1,69 & 0,14 & 1,22 & 4,38 & 0,12 \\
\hline Jumlah (2) & $2.224,15$ & $1.423,90$ & 118,66 & $1.027,35$ & $3.698,45$ & 100,00 \\
\hline Ketersediaan (1-2) & 692,94 & 443,62 & 36,97 & 320,07 & $1.152,26$ & \\
\hline
\end{tabular}


Tabel 4. Rata-rata total pengeluaran rumah tangga petani kelapa sawit dalam satu bulan

\begin{tabular}{rlrr}
\hline No & Jenis pengeluaran & Jumlah (Rp) & \multicolumn{1}{c}{$(\%)$} \\
\hline & Pangan & & \\
1 & Pangan Pokok & & \\
& Beras & $255.866,67$ & 30,42 \\
& Bukan beras & $21.375,00$ & 2,54 \\
2 & Lauk-Pauk & $154.284,44$ & 18,34 \\
3 & Kacang-Kacangan & $5.447,78$ & 0,65 \\
4 & Sayuran & $84.313,02$ & 10,02 \\
5 & Buah-buahan & $21.545,05$ & 2,56 \\
6 & Lemak & $78.840,00$ & 9,37 \\
7 & Makanan Jajanan & $50.265,57$ & 5,98 \\
8 & Minuman & $72.153,33$ & 8,58 \\
9 & Bumbu & $96.972,67$ & 11,53 \\
& Total & $841.063,52$ & 50,52 \\
\hline & Non Pangan & & \\
10 & Listrik & $95.746,67$ & 5,75 \\
11 & Gas & $39.213,33$ & 2,35 \\
12 & Bahan bakar & $122.133,33$ & 7,33 \\
13 & Rokok & $119.733,33$ & 7,19 \\
14 & SPP & $53.894,44$ & 3,24 \\
15 & Uang saku & $151.200,00$ & 9,08 \\
16 & Pakaian & $65.388,89$ & 3,93 \\
17 & Kesehatan & $4.600,00$ & 0,28 \\
18 & Arisan & $19.333,33$ & 1,16 \\
19 & Komunikasi & $41.400,00$ & 2,49 \\
20 & Sabun & $73.140,00$ & 4,39 \\
21 & Kecantikan & $9.535,56$ & 0,57 \\
22 & Sumbangan & $28.266,67$ & 1,70 \\
& Total & $823.585,56$ & 49,48 \\
\hline & Total pengeluaran & $1.664 .649,08$ & 100,00 \\
\hline & & &
\end{tabular}

\section{Distribusi (akses pangan)}

Akses pangan ditunjukkan oleh kemampuan memproduksi pangan, infrastruktur dan kondisi sumber daya alam dan lingkungan pada wilayah tersebut. Sebagian besar rumah tangga petani kelapa sawit di Kecamatan Bangunrejo memiliki akses pangan secara langsung (72\%), sedangkan sisanya 28 persen tidak memiliki akses pangan secara langsung. Bahan pangan tersedia di pasar atau warung yang ada pada lokasi penelitian dengan harga yang terjangkau.

\section{Konsumsi pangan}

Konsumsi pangan adalah jenis dan jumlah pangan yang dikonsumsi oleh seseorang dengan tujuan untuk memenuhi kebutuhan individu secara biologis, psikologi maupun sosial pada waktu tertentu. Tingkat konsumsi energi rumah tangga akan menentukan tingkat ketahanan pangan rumah tangga petani kelapa sawit di Kecamatan Bangunrejo. Beras memiliki jumlah konsumsi tertinggi yaitu sebesar 248,96 gram/kapita/hari atau 1.742 gram/kapita/minggu. Konsumsi beras menurut BPS (2019) mencapai 1.551 gram/kapita/minggu yang dapat dikatakan masih rendah dibandingkan dengan hasil penelitian. Beras adalah pokok yang setiap harinya dikonsumsi oleh petani di lokasi penelitian yang dapat mendukung upaya pencapaian ketahanan pangan dan mengatasi kekurangan gizi.

\section{Analisis Ketahanan Pangan Rumah Tangga}

Ketahanan pangan rumah tangga petani kelapa sawit diukur berdasarkan klasifikasi silang antara pangsa pengeluaran pangan dengan jumlah kecukupan energi yang dikembangkan Jonsson dan Toole (1991) dalam Maxwell et al. (2000).

\section{Pangsa Pengeluaran Pangan}

Pangsa pengeluaran pangan adalah besarnya jumlah pengeluaran rumah tangga untuk belanja pangan dari jumlah total pengeluaran rumah tangga. Rata-rata pengeluaran pangan rumah tangga petani kelapa sawit di Kecamatan Bangunrejo dalam satu bulan adalah Rp841.063,52 per bulan atau 50,52 persen dari total pengeluaran rumah tangga petani. Rata-rata pengeluaran nonpangan rumah tangga petani dalam satu bulan adalah sebesar Rp823.585,56 atau 49,48 persen. Hal ini menunjukkan bahwa pengeluaran pangan lebih besar dari pengeluaran non-pangan. Pengeluaran pangan terbesar adalah beras, hal tersebut dikarenakan beras merupakan pangan pokok. Pengeluaran non-pangan terbesar adalah uang saku yaitu Rp151.200,00 atau 9,08 persen. Hal tersebut dikarenakan sebagian besar anggota keluarga petani kelapa sawit masih bersekolah. Akses pendidikan yang cukup jauh serta biaya pendidikan menjadi alasan rumah tangga petani kelapa sawit mengeluarkan dana yang cukup besar untuk keperluan uang saku setiap hari. Rata-rata total pengeluaran rumah tangga petani kelapa sawit dalam satu bulan dapat dilihat pada Tabel 4 .

Tabel 5. Rata-rata konsumsi riil energi rumah tangga petani kelapa sawit

\begin{tabular}{llr}
\hline \multirow{2}{*}{ No } & \multirow{2}{*}{ Golongan pangan } & Rata-rata konsumsi \\
\cline { 2 - 3 } 1 & Padi-padian & Energi (kkal) \\
2 & Umbi-umbian & $3.115,54$ \\
3 & Pangan hewani & 62,36 \\
4 & Minyak dan lemak & 679,33 \\
5 & Buah biji berminyak & 438,09 \\
6 & Kacangan & 39,19 \\
7 & Gula & 714,94 \\
8 & Sayur dan buah & 127,07 \\
9 & lain-lain & 233,12 \\
\hline Total & 329,51 \\
\hline AKE & $5.739,14$ \\
\hline TKE & $6.947,16$ \\
\hline
\end{tabular}


Tabel 6. Sebaran tingkat kecukupan energi rumah tangga petani kelapa sawit

\begin{tabular}{lccc}
\hline \multicolumn{1}{c}{ Indikator } & Kategori & Jumlah (n) & $(\%)$ \\
\hline Energi & & & \\
\hline$>80 \%$ & Cukup & 53 & 70,67 \\
$\leq 80 \%$ & Kurang & 22 & 29,33 \\
\hline Jumlah & & 75 & \\
\hline
\end{tabular}

Setelah diperoleh total pengeluaran pangan maka dapat dihitung pangsa pengeluaran pangan. Berdasarkan hasil perhitungan, rumah tangga dengan pangsa pengeluaran pangan $<60$ persen sebanyak 67 rumah tangga $(89,33 \%)$, sedangkan rumah tangga dengan pangsa pengeluaran pangan $\geq 60$ persen sebanyak delapan rumah tangga (10,67\%). Pangsa pengeluaran pangan yang rendah menunjukkan tingkat pendapatan yang tinggi sehingga untuk mendapatkan pangan juga tinggi, begitu juga sebaliknya.

\section{Tingkat Kecukupan Energi}

Angka kecukupan energi dalam penelitian ini mengacu pada Widyakarya Nasional Pangan dan Gizi (WNPG) X Tahun 2012. Rata-rata konsumsi energi total rumah tangga petani kelapa sawit di Kecamatan Bangunrejo adalah sebesar 5.739,14 kkal atau 1.703 kkal per kapita dengan AKE sebesar 84,42 persen. Rata-rata konsumsi riil energi rumah tangga petani kelapa sawit di Kecamatan Bangunrejo dapat dilihat pada Tabel 6.

Bedasarkan Tabel 6 dapat dilihat bahwa rata-rata konsumsi energi terbesar adalah padi-padian, Sebab seluruh rumah tangga mengkonsumsi beras sebagai makanan pokok sumber karbohidrat. Konsumsi energi masih berada di bawah standar AKE yang dianjurkan dalam WNPG $\mathrm{X}$ Tahun 2012. Tingkat kecukupan energi dibagi menjadi dua kriteria yaitu cukup $(>80 \%)$ dan kurang ( $\leq$ $80 \%$ ). Rata-rata rumah tangga petani kelapa sawit $(70,67 \%)$ memiliki tingkat kecukupan energi yang tergolong dalam kategori cukup. Sebaran tingkat kecukupan energi rumah tangga petani kelapa sawit dapat dilihat pada Tabel 7.

\section{Tingkat Ketahanan Pangan Rumah Tangga}

Berdasarkan klasifikasi silang antara pangsa pengeluaran pangan dengan jumlah kecukupan energi, tingkat ketahanan pangan rumah tangga petani kelapa sawit dapat dilihat pada Tabel 7 . Hasil analisis menunjukkan bahwa rumah tangga petani kelapa sawit didominasi oleh rumah tangga yang tahan pangan $(61,33 \%)$, sedangkan sisanya kurang (28\%), rentan $(9,33 \%)$, dan rawan pangan $(1,33 \%)$.

Rumah tangga petani kelapa sawit di Kecamatan Bangunrejo yang termasuk dalam kategori tahan pangan sebesar 61,33 persen, ditunjukkan dengan pangsa pengeluaran pangan yang rendah dan TKE yang cukup. Pangsa pengeluaran pangan yang rendah menyebabkan proporsi pendapatan yang dikeluarkan untuk belanja pangan lebih sedikit sehingga dari sisi ketersediaan pangan dapat tercukupi dengan baik dan berpengaruh terhadap kuantitas konsumsi pangan yang cukup untuk memenuhi kebutuhan energinya.

Rumah tangga petani kelapa sawit yang tergolong kurang pangan sebanyak 28 persen dengan ratarata TKE sebesar 72,78 persen dan pangsa pengeluaran pangan sebesar 46,75 persen. Hal ini menunjukkan bahwa kebutuhan energi rumah tangga belum tercukupi, tetapi sebenarnya memiliki daya beli dan akses yang tinggi terhadap pangan karena pangsa pengeluaran pangan rendah yang mengindikasikan bahwa rumah tangga memiliki pendapatan yang tinggi.

Rumah tangga petani kelapa sawit yang tergolong rentan pangan hanya sebesar 9,33 persen dengan rata-rata TKE sebesar 90,65 persen dan pangsa pengeluaran pangan sebesar 63,89 persen. Hal ini menunjukkan bahwa rumah tangga rentan pangan telah berhasil mencukupi kebutuhan energi hariannya, akan tetapi memiliki pangsa pengeluaran pangan tinggi yang mengindikasikan bahwa rumah tangga tersebut memiliki pendapatan yang relatif rendah, sehingga sebagian besar pendapatannya dikeluarkan untuk belanja pangan. Pendapatan yang rendah mengakibatkan daya beli dan akses rumah tangga terhadap pangan rendah.

Satu rumah tangga petani kelapa sawit tergolong rawan pangan dengan rata-rata TKE sebesar 59,11 persen dan pangsa pengeluaran pangan sebesar 61,89 persen.

Tabel 7. Tingkat ketahanan pangan rumah tangga petani kelapa sawit

\begin{tabular}{|c|c|c|c|c|c|}
\hline \multirow{2}{*}{ No } & \multirow{2}{*}{$\begin{array}{c}\text { Tingkat } \\
\text { Ketahanan } \\
\text { Pangan }\end{array}$} & TKE & PPP & \multirow{2}{*}{$\begin{array}{c}\text { Jumlah } \\
\text { (n) }\end{array}$} & \multirow{2}{*}{$(\%)$} \\
\hline & & $(\%)$ & $(\%)$ & & \\
\hline 1 & Tahan & 89,80 & 52,51 & 46,00 & 61,33 \\
\hline 2 & Kurang & 71,78 & 46,75 & 21,00 & 28,00 \\
\hline 3 & Rentan & 90,65 & 63,89 & 7,00 & 9,33 \\
\hline 4 & Rawan & 59,11 & 61,89 & 1,00 & 1,33 \\
\hline
\end{tabular}


Rumah tangga rawan pangan ini memiliki pangsa pengeluaran pangan yang tinggi dan kebutuhan energi hariannya belum tercukupi. Rawan pangan terjadi karena pendapatan yang rendah, sehingga tidak mampu mengakses pangan sesuai kebutuhan yang berdampak kebutuhan energi tidak terpenuhi.

\section{Faktor-Faktor yang Memengaruhi Tingkat Ketahanan Pangan Rumah Tangga Petani Kelapa Sawit di Kecamatan Bangunrejo}

Faktor yang berpengaruh positif terhadap peluang petani untuk tahan pangan adalah tingkat pendidikan ibu rumah tangga $\left(\mathrm{X}_{2}\right)$ dan pendapatan rumah tangga $\left(\mathrm{X}_{5}\right)$ sedangkan faktor yang berpengaruh negatif terhadap peluang petani untuk tahan pangan adalah jumlah anggota keluarga $\left(\mathrm{X}_{1}\right)$.

Pseudo R-Square sebesar 0,1152. Artinya, sebesar 11,52 persen variasi peluang rumah tangga untuk tahan pangan dapat dijelaskan oleh variabel jumlah anggota keluarga, pendidikan ibu, harga beras, harga telur, pendapatan, dan akses pangan. Nilai probability Likelihood Ratio statistik sebesar 0,0129 menjelaskan bahwa variabel jumlah anggota keluarga, pendidikan ibu rumah tangga, harga beras, harga telur, pendapatan, dan akses pangan secara bersama-sama berpengaruh nyata terhadap peluang petani untuk tahan pangan. Hasil analisis regresi ordinal logit faktor-faktor yang memengaruhi ketahana pangan dapat dilihat pada Tabel 9.

Variabel jumlah anggota keluarga berpengaruh negatif terhadap peluang petani untuk tahan pangan dengan tingkat kepercayaan sebesar 99 persen.

Tabel 8. Hasil regresi ordinal logit faktor-faktor yang memengaruhi ketahanan pangan

\begin{tabular}{lrrr}
\hline \multicolumn{1}{c}{ Variable } & Coefficient & Prob. & $\begin{array}{c}\text { Odd } \\
\text { Ratio }\end{array}$ \\
\hline $\begin{array}{lrrr}\text { Jumlah anggota keluarga } \\
\left(X_{1}\right)\end{array}$ & $-0,9076^{* * *}$ & 0,0043 & 0,4033 \\
Pendidikan ibu rumah & & & \\
tangga $\left(\mathrm{X}_{2}\right)$ & $0,3352 * *$ & 0,0121 & 1,3986 \\
Harga beras $\left(\mathrm{X}_{3}\right)$ & $-0,0003$ & 0.8047 & 0,9997 \\
Harga telur $\left(\mathrm{X}_{4}\right)$ & 0,0011 & 0,5145 & 1,0011 \\
Pendapatan $\left(\mathrm{X}_{5}\right)$ & $4,90 \mathrm{E}-07 *$ & 0,0892 & 1,0000 \\
Akses Pangan $\left(\mathrm{D}_{1}\right)$ & 0,5587 & 0,3870 & 1,7492 \\
\hline Pseudo R-squared & 0,1152 & & \\
LR statistic & 16,1537 & & \\
Prob(LR statistic) & 0,0129 & & \\
\hline Ketrangan: & & & \\
\hline
\end{tabular}

\section{Keterangan:}

****berpengaruh nyata taraf kepercayaan $99 \%$

** berpengaruh nyata pada taraf kepercayaan $95 \%$

* berpengaruh nyata pada taraf kepercayaan $90 \%$
Rata-rata anggota rumah tangga petani kelapa sawit adalah empat orang. Hasil penelitian ini sejalan dengan Yuliana, Zakaria dan Adawiyah (2013) yang menyatakan bahwa terdapat hubungan negatif antara jumlah anggota keluarga dengan tingkat ketahanan pangan. Semakin besar jumlah anggota keluarga maka semakin kecil peluang tercapainya ketahanan pangan. Sebagian besar rumah tangga petani kelapa sawit memiliki jumlah anggota keluarga sebanyak empat orang dan anggota keluarga tersebut belum memiliki pekerjaan sehingga tidak memberikan kontribusi dalam membantu mencukupi kebutuhan keluarga.

Variabel tingkat pendidikan ibu rumah tangga berpengaruh positif terhadap peluang petani untuk tahan pangan dengan tingkat kepercayaan sebesar 95 persen. Hasil penelitian ini sejalan dengan penelitian Delly, Prasmatiwi dan Prayitno (2019) yang menyatakan bahwa tingkat pendidikan ibu rumah tangga berpengaruh positif terhadap tingkat ketahanan pangan. Tingkat pendidikan ibu rumah tangga berkaitan dengan kemampuan dan pola pikir ibu rumah tangga dalam mengambil keputusan yang berhubungan dengan ketahanan pangan. Semakin tinggi tingkat pendidikan ibu rumah tangga maka semakin rasional mengambil keputusan mengenai pola konsumsi rumah tangga.

Variabel pendapatan rumah tangga berpengaruh positif terhadap peluang petani untuk tahan pangan dengan tingkat kepercayaan sebesar 90 persen. Hasil ini sejalan dengan Anggraini, Zakaria dan Prasmatiwi, (2014) yang menyatakan bahwa pendapatan rumah tangga berpengaruh positif terhadap tingkat ketahanan pangan. Peningkatan pendapatan rumah tangga menunjukkan bahwa penggunaan pendapatan tidak seluruhnya untuk pengeluaran pangan, namun dialokasikan pula untuk memenuhi kebutuhan non pangan. Hal tersebut dapat menyebabkan pangsa pengeluaran pangan menurun sehingga derajat tahan pangan akan tercapai. Besarnya pendapatan rumah tangga juga dapat mempermudah akses, dimana pendapatan merupakan proksi untuk daya beli rumah tangga.

\section{Upaya untuk Mencapai Kondisi Tahan Pangan}

Upaya pemerintah terdiri dari pemantauan ketersediaan pangan, distribusi dan cadangan pangan (pembuatan lumbung pangan), pengembangan penganekaragaman konsumsi dan keamanan pangan, Program Keluarga Harapan $(\mathrm{PKH})$, Raskin, dan Bantuan Pangan Non Tunai (BPNT). Upaya rumah tangga petani kelapa sawit 
adalah meminjam bahan baku pangan $(93,33 \%)$, sisanya akan mengubah kualitas pangan yang dikonsumsi dan mengurangi porsi makan. Keseluruhan petani yang meminjam bahan pangan diantaranya 18,67 persen juga mengubah pola makan, 6,67 persen akan mempekerjakan anggota keluarga, dan 6,67 persen akan melakukan usahatani lain dan melakukan usaha di luar pertanian guna mencukupi kebutuhan pangan.

\section{KESIMPULAN}

Mayoritas rumah tangga petani kelapa sawit di Kecamatan Bangunrejo tergolong dalam kategori tahan pangan $(61,33 \%)$, sisanya sebanyak 28 persen tergolong kurang pangan, 9,33 persen tergolong rentan pangan, dan 1,33 persen tergolong rawan pangan. Faktor yang berpengaruh positif terhadap peluang rumah tangga petani untuk tahan pangan yaitu tingkat pendidikan ibu rumah tangga dan pendapatan rumah tangga. Faktor yang berpengaruh negatif terhadap peluang rumah tangga petani untuk tahan pangan adalah jumlah anggota keluarga. Upaya yang dilakukan pemerintah terdiri dari pemantauan ketersediaan pangan, distribusi dan cadangan pangan, pengembangan penganekaragaman konsumsi dan keamanan pangan, melakukan program bantuan meliputi PKH, Raskin, dan BPNT. Upaya yang dilakukan oleh rumah tangga petani kelapa sawit mencapai kondisi tahan pangan adalah meminjam bahan pangan $(93,33 \%)$ dan mengubah pola makan $(6,67 \%)$ dengan mengurangi porsi makanan yang dikonsumsi oleh rumah tangga.

\section{DAFTAR PUSTAKA}

Anggraini M, Zakaria WA, dan Prasmatiwi FE. 2014. Ketahanan pangan rumah tangga petani kopi di Kabupaten Lampung Barat. Jurnal Ilти-Ilmu Agribisnis. 2 (2):124-132. http://jurnal.fp.unila.ac.id/index.php/JIA/articl e/view/737/678. [15 November 2018].

BPS [Badan Pusat Statistik]. 2015. Konsumsi Rata Rata per Kapita Seminggu Beberapa Macam Bahan Makanan Penting, 2007-2015. BPS Jakarta.

BPS [Badan Pusat Statistik] Propinsi Lampung. 2018a. Lampung dalam Angka. Penerbit BPS
Provinsi Lampung. Lampung.

BPS [Badan Pusat Statistik] Provinsi Lampung. 2018b. Indikator Kesejahteraan Rakyat Provinsi Lampung. Penerbit BPS Provinsi Lampung. Lampung.

BPS [Badan Pusat Statistik]. 2019. Kosumsi dan Pengeluaran.Penerbit BPS Indonesia.

Delly PD, Prasmatiwi FE, dan Prayitno RT. 2019. Tingkat ketahanan pangan rumah tangga nelayan di Desa Sukajaya Lempasing, Kecamatan Teluk Pandan Kabupaten Pesawaran. Jurnal Ilmu-Ilmu Agribisnis. 7 (2):141-148. http://jurnal.fp.unila.ac.id/ index.php/ JIA/ article/view/3373/ 2575. [20 September 2019].

Lalita R, Ismono RH, dan Prasmatiwi FE. 2018. Kajian sosial ekonomi dan tingkat kesejahteraan rumah tangga petani kelapa sawit di Kabupaten Tulang Bawang. Jurnal Ilmu-Ilmu Agribisnis. 7 (2): 195 - 202. http://jurnal.fp.unila.ac.id/index.php/JIA/articl e/view/3381/2582. [15 November 2018].

Maryani S, Prasmatiwi FE, dan Adawiyah R. 2017. Ketersediaan pangan dan faktor-faktor yang mempengaruhi ketersediaan pangan rumah tangga petani padi anggota lumbung pangan di Kecamatan Ambarawa Kabupaten Pringsewu. Jurnal Ilmu Ilmu Agribisnis. 5 (3): 304

311. http://jurnal.fp.unila.ac.id/index.php/JIA/articl e/view/1643/1469. [15 November 2018].

Maxwell D, Levin C, Klemesu MA, Ruel M, Morris S, dan Ahiadeke C. 2000. Urban Livelihoods and Food Nutition Security in Greater Accra, Ghana. IFPRI in Collaborative with Noguchi Memorial for Medical Research and World Health Organization, Research Report No. 112. Washington, D.C.

Sugiarto D. 2003. Teknik Sampling. PT Gramedia Pustaka Utama. Jakarta.

Yuliana P, Zakaria WA, dan Adawiyah R. 2013. Ketahanan pangan rumah tangga nelayan di Kecamatan Teluk Betung Selatan Kota Bandar Lampung. Jurnal Ilmu Ilmu Agribisnis. 1(2):181-186. http://jurnal.fp.unila.ac.id/index.php/JIA/articl e/view/246/245. [15 November 2018]. 